\title{
Gender Identity in Toni Morrison's Tar Baby
}

\author{
Ahmed Seif Eddine Nefnouf \\ $\mathrm{PhD}$ Candidate \\ Literary Studies/ Szeged University \\ Szeged, Hungary \\ ahmednefnouf@gmail.com
}

In this paper, I am going to conduct a feminist reading of Tar Baby by using feminist theory. We are going to look at the issues of gender identity according to feminist's ideologies and principles in term of oppression against black in general and black women specifically. In addition to that, we are going to use one of the main principles of feminism, which is the patriarchy system between gender and origin. This analysis based on the actions, thoughts and behaviors of the major characters in Toni Morrison's Tar Baby to gain their identity, also to understand the nature of gender inequality and examining women's social roles, experience and interests

Keywords - Blacks, Whites, Racism, Identity

\section{Introduction}

Identity is a very recurrent theme in African American novels; because the search for identity is natural for every human being. From the very beginning of their presence in America, the black were subjected to slavery, their basic human rights have been often violated and they suffered from all forms of humiliation. Thus, the search of identity is 
pictured in the literary works. Writers such as Richard Wright in his novel Native Son dealt with the issues of identity and racism; Alice Walker in her novel The Color Purple is about women double discrimination and their identity troubles.

Toni Morrison is a prominent Afro-American writer; her well known novel Tar Baby represents the dilemma of identity. This issue shows its power as one of the main thematic concerns of African American literature. Her novels are deeply concerned with the issues of gender and identity. She has often been known as a voice of African American culture, and she addressed the position of African American person and specifically women in the contemporary world.

\section{Gender Identity}

Gender identity in generally defined as a personal conception of oneself as male or female

\subsection{Oppression}

The word feminism is generally defined as the movement to end women's oppression (Hooks, 2000). Most of feminists see the word "woman" as a gender; which depends on social, economic, psychological, and cultural factors such as social position. Their criticism have a relation with "...the ways in which literature (and other cultural production) reinforce or undermine the economic, political, social, and psychological oppression of women" (Tyson, 2015).

\subsubsection{Social/Cultural}

Social norms, roles, rituals, language, music, and art that reflect and reinforce the belief that one social group is superior to another (Hardiman, Jackson \& Griffin, 2010). 
For Jadine, she is a black beautiful girl and one of the novel's protagonists. She works as a model. Valerian Street paid for her studying of arts and history in Paris .She was helped by Ondine and Sydney in her life to give her the sense of family, vis-à-vis, she did not care for them. She interested in arts, urban life, fashion and culture. She used to be confused about her feelings and thoughts because she was free person. She fell in love with Son while she met him in the island.

So in Tar Bar the gender is a recurring theme, because Jadine gets afraid about her position as black woman, but the fact that she is a woman is more significant than the fact that she is black. Jadine felt as she sacrificing herself when she decided to live with Son's hometown of Eloe, because she will be home mum without any chance to get her personal and individual ambitions. So, she decided to go to the white world, because; she thinks that this world provides her the opportunity to be a real woman.

They stood around the room jostling each other gently, gently-there wasn't much room- revealing one breast and then two and Jadine was shocked

(TB, ch9, p191)

Jadine visited son's hometown of Eloe, when she is staying there, she shocked when a black woman start pulling out their breasts in front of him; this action meant to Jadine that this is the way these woman wants to be (to make him as traditional gender), and will be just mum. Thus, was in contradiction to what Jadine wants to be. According to her position as civilized girl who studied in Paris and well educated in fashion and arts, also she consideres herself as model girl and she has many ambitions to reach not like other Gender ; which they have to obey other male roles and live just like mum. So, Jadine in this case shaped her gender by her social position as a model and well educated woman. 
He tried to imagine what kind of woman she would be in fifty years. Would she be Thérèse? Or Ondine? Or Rosa or Sally Brown, or maybe even Francine, frail as a pick tearing all her hair out in the hospital.

(TB, ch9, p198)

In this example the male character, Son, looks at the female gender and think of women will become, he did not imagine that Jadine will be very successful. He thinks about the idea of Jadine who is the woman live for herself not for someone else like Thérèse, Ondine and other female characters. This is completely unaccepted in son's point of view as a male.

As in feminism ideologies, the male have all major social institutions and dominant and controlled by him in economy, political, system, and family religion.

Now he sat in the December sunlight watching his servant pour coffee into his cup.

"Has it come?"

"Sir?"

"The salve."

"Not yet." Sydney removed the lid from a tiny box of saccharin tablets and edged it toward his employer.

(TB, ch1, p15)

Valerian who is the owner of L'Arbre De La Croix, white and wealthy man who retired from candy manufacture, controls his servants; also most of them are women so they feel oppressed. 
Also, in this quotation "I do know that and I know my kitchens. Better than I know my face."'(TB, ch1, p38) as we explained before that she is a servant; in this case her occupation forced him to neglect her beauty as woman because she works in house of male and white owner, obviously she does not find time to care about herself as a woman and she used to cook and work in the kitchens. So, she forgot about her identity as a woman.

\subsubsection{Personal}

Which are actions and attitudes that reflect prejudice against a social group (Hardiman, Jackson \& Griffin, 2010).

\footnotetext{
"She thought she was rescuing him from the night women who $[\ldots]$ wanted her to settle for wifely competence when she could be almighty, to settle for fertility rather than originality, nurturing instead of building."
}

(TB, ch9, p198)

Jadine wants to realize her goals and ambitions by travelling the world and being famous model, after visit Eloe which is the hometown of Son she realizes that she will be just wife and mother of kids, but Jade will not accept this kind of life because she wants to be a real woman.

I don't want to learn how to be the kind of woman you're talking about because I don't want to be that kind of woman.

(TB, ch10, p89)

In this quote Jadine response to her aunt Ondine about the issues of being a real female, she want to live for herself not to another one, she does not to be a worker like the servant of the house or a mother of kids, also achieve her objectives for her life. 
For son, "That was why she was ashamed. He was the one who smelled [...] Treating her like another animal and both of them must have looked just like it in that room. One dog sniffing at the hindquarters of another and the female, her back to him, not moving. "

(TB, ch4, p93)

When Son makes bad things with smell her hair, Jadine thought that she is like animals because smell is animal behavior. So she feels shamed, because of her occupation as educated and civilized woman. After that she recognized that she equals nothing than female animal because he told her that her smell like everything else Jade feels Ashamed. So the male character in this case is in power against female because he treated her as an animal applies his dominant over her.

Son's sexual behavior against him makes Jadine react by hitting him in his face (because he rape her), feminists define rape as "committed overwhelmingly by men and boys, usually against women and girls" appears in this quotation; "but she was hitting him in the face and on the top of his head" (TB, ch4, p92).

\footnotetext{
"It was easy not to believe in Margaret's hysteria; he had seen examples of it many times before and thought she was up to her old combo of masochism plus narcissism that he believed common to exceptionally beautiful women."
}

(TB, ch5, p105)

\begin{abstract}
Also, here valerian continued his blame against Margaret which is the way to neglect him by throwing negative words and emotions because women are irrational. Valerian again thinks that pretty women do not take about their position as real women, but to be just spoiled.
\end{abstract}


As known the feminism theory comes to end oppression against woman, in this novel the oppression appeared when the character Ondine She complained to her husband to take her from this place

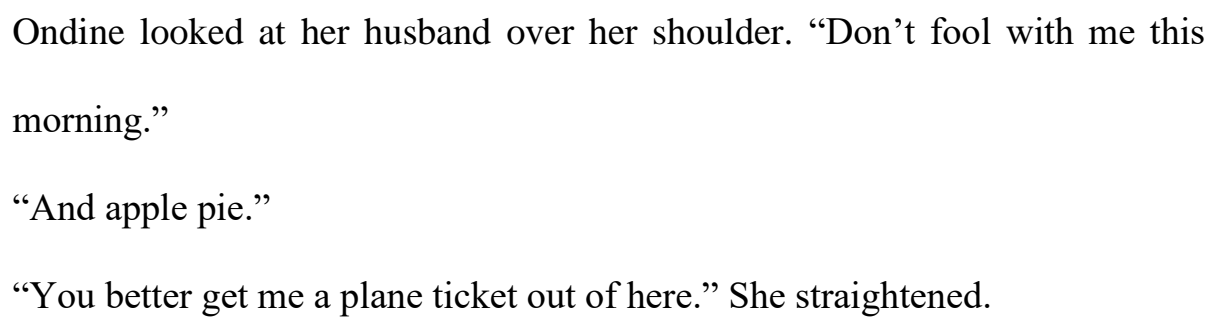

Ondine feels that she is not a real woman because of her social position as a servant in a house full of oppression, so she decided to leave it to find another life differ from this one which controlled by male character

\subsubsection{Institutional}

Policies, laws, rules, norms, and customs enacted by organizations and social institutions that disadvantage some social groups and advantage other social groups. These institutions include religion, government, education, law, the media, and health care system (Hardiman, Jackson \& Griffin, 2010).

I wonder if the person he wants to marry is me or a black girl? And if it isn't me he wants, but any black girl who looks like me, talks and acts like me, what will happen when he finds out that I hate ear hoops, that I don't have to straighten my hair, that Mingus puts me to sleep, that sometimes I want to get out of my skin and be only the person inside — not American — not blackjust me?

$(\mathrm{TB}, \mathrm{ch} 2, \mathrm{p} 42)$

When she had to make an important decision: there were three men who wanted to marry her and the favorite named Ryk is a white rich boy: she is concerned however that he wants to marry her only because she is black while in truth she rejects all forms of blackness and black 
culture and that she sometimes even wishes she could get out of her skin so as not to be black or American but just herself. This quote addressed many massages from Jadine; first she wants to free not American (origin) and not black (racial identity), but women as she wants to be modern women not traditional one.

[They] did not wish to see the crying, crying girls split in two parts by their tight jeans, screaming at the top of their high, high heels, straining against the pull of their braids and the fluorescent combs holding their hair.

(TB, ch7, p161)

This happened when Son gets to new York with Jadine; he finds many prostitutes on the corners' street and most of them are black, that what makes him ashamed to get a look to them because they are selling their bodies to white male, also it is hard for black male.

Ondine was just about to show her how to make crust (and Margaret by then knew the honor of the offer, since Ondine didn't like sharing recipes or kitchen space) when Valerian put a stop to it saying she should guide the servants, not consort with them.

(TB, ch2, p48)

This quote clarifies the fact that man are controlled woman; first when Valerian tells Margaret to guide the servants not consort with them, second when Margaret applies this order against the servants. This case explains the power position of male over female in terms of controlling them in the system, family etc.

As known the feminism theory comes to end oppression against woman, in this novel the oppression appeared when the character Ondine She complained to her husband to take her from this place

Ondine looked at her husband over her shoulder. "Don't fool with me this morning." 
"And apple pie."

"You better get me a plane ticket out of here." She straightened.

(TB, ch1, p32)

Ondine feels that she is not a real woman because of her social position as a servant in a house full of oppression, so she decided to leave it to find another life differ from this one which controlled by male character

[If a girl] never learns to be a daughter, she can't never learn how to be a woman. I mean a real woman: a woman good enough for a child; good enough for a man - good enough even for the respect of other women.

(TB, ch10, p207)

According to Ondine, the girls cannot acquire the role to be a woman otherwise she realizes her function toward family. So, women need to take care of family and kids unlike others. Thus means that the woman is like good; for kids, man, and the respect of other woman.

\section{Patriarchy}

One of the main principles of feminist is the patriarchy of male against females, they feel male in power over them, and so they feel some fear (Hooks, 2000).

\subsection{Male Vs Female}

Jadine thinks that:

White but European which was not as bad as white and American; they would understand that, or would they? Had they ever said? They liked her being in Paris, the schools she'd gone to, the friends she'd had there.

(TB, ch2, p43) 
So, Jadine in this quotation means that all males patriarchal; nor American neither European, because they are in power over female even though European lesser than American because she lived, worked, and studied there. She knew everything about them in terms of civilization, education and so on.

Also, when Ondine tells Sydney that:

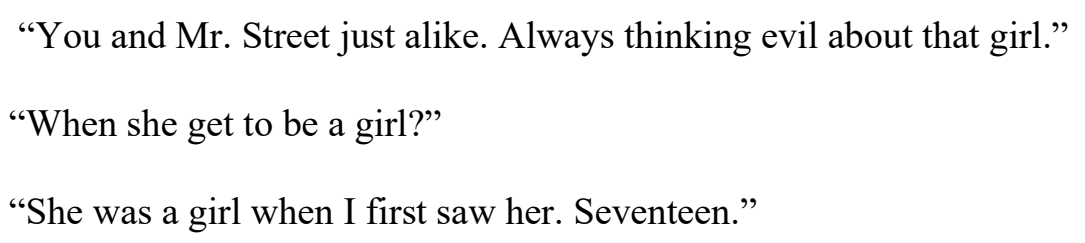

(TB, ch1, p34)

In this quotation, we can infer that men are domination over women within American society i.e. they followed the patriarchy system. Thus, she insults Mr. Street and Sydney by they are always thinking evil about that girl. In this matter, she refers back to the ideology of sixteenth century that men controlled everything in the society.

The face in the peaches compelled him to dismiss Margaret's screaming entrance as the tantrum of a spoiled child, the deliberate creation of a scene, which both father and son understood as feminine dementia.

(TB, ch5, p105)

Valerian blames Margaret in everything even she gets upset; he used to blame her in the fact that she is a woman. In addition to that he uses the issues of gender many times in the novel to neglect them by blame and takes woman's opinion seriously.

"I don't have to sit here and be called names!"

"Idiot. I married an idiot!"

"And I married an old fool!" 
"Of course you did. Who else but an old fool would marry a high school dropout off the back of a truck!"

"A float!" Margaret shouted, and when the wineglass bounced from the centerpiece of calla lilies and rolled toward him he didn't even look at it. He simply watched his wife's face crumple and her boy-blue eyes well up."

(TB, ch3, p57)

In this example the female character Margaret tried to get angry on the male character ( her husband), but she does not succeeded because of the dominance of male is applied on Margaret when the wineglass rolled toward him and get afraid of her husband Valerian reaction.

\subsection{White Vs Black}

When Jadine is in her room laying in the fur coat, she thinks about her blackness she finds the black men standing in her room. After a long conversation about clothes and jewelry he wants to do sexual action with her, but she refuses and says: She stood with her back to him, rubbing her wrists. She said: "I'll have to tell Valerian.”(TB, ch4, p93)

Thus, means that she controlled by white male the owner of the house Jadine wants to tell him about everything that Son did with him. She is a woman and cannot control herself because of her social position in this house unlike Paris.

““'LAUGHING?” Margaret could not believe her ears.

"I'm telling you! They were in there laughing! I was looking right at them when you called out the window."

"Good God. What's gotten into him?"

"I don’t know."

"Are you scared?" 


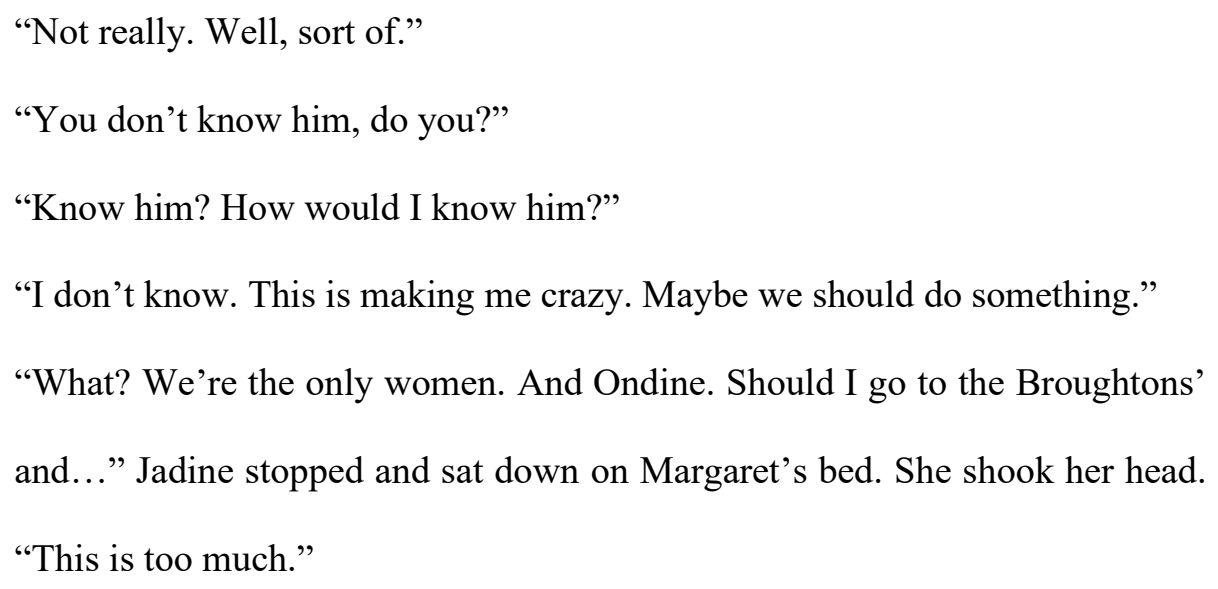

(TB, ch5, p96)

In this example the role of women and gender is very obvious by most of female character because Jadine reports to Margaret that Valerian and the man was laughing together, and discusses what they should do about him. So, they decided to call police because they feel scared or think about their position.

\section{Conclusion}

Through this paper, we have induced some important quotes to find and understand position and reaction of black towards oppression and both racial segregation and social discrimination to get their identity in white and racist society. We have analyzed Tar Baby with a feminism theory, we have concentrated first on: the principle of oppression and its type like Social/cultural, Personal and Institutional oppression. Second: patriarchy system between black and white, and male and female. We have concentrated on reason behind the characters' problem of identity in the novel. We have shown the fact that gender identity has a relation with the race's differences. 


\section{Works Cited}

Hardiman, R., Jackson, B. W., \& Griffin, P. Conceptual foundations. In B. Adams, Castaneda, Hackman, Peters \& Zuniga (Eds.), Readings for diversity and social justice (pp. 26-35).2010.

Hooks, Bell. Feminist Theory: from Margin to Center. South End Press, 2000.

Morrison, Toni. Tar Baby. Paw Prints, 2008.

Tyson, Lois. Critical Theory Today: a User-Friendly Guide. Routledge, 2015. 